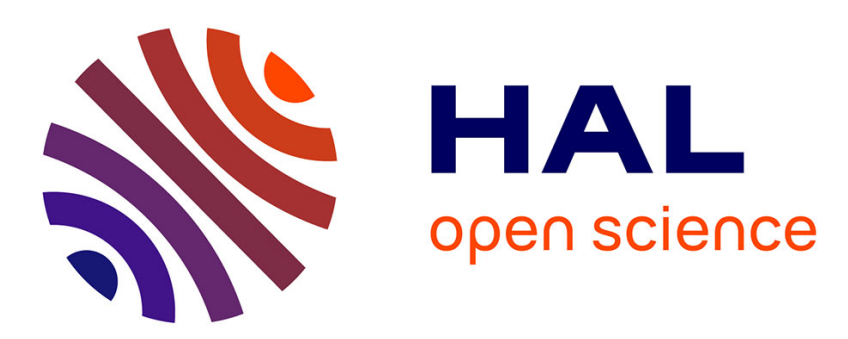

\title{
Social Capital and Voting Participation of Immigrants and Minorities in Canada
}

Pieter Bevelander, Ravi Pendakur

\section{To cite this version:}

Pieter Bevelander, Ravi Pendakur. Social Capital and Voting Participation of Immigrants and Minorities in Canada. Ethnic and Racial Studies, 2009, 32 (8), pp.1406-1430. 10.1080/01419870802298447. hal-00521094

\section{HAL Id: hal-00521094 \\ https://hal.science/hal-00521094}

Submitted on 25 Sep 2010

HAL is a multi-disciplinary open access archive for the deposit and dissemination of scientific research documents, whether they are published or not. The documents may come from teaching and research institutions in France or abroad, or from public or private research centers.
L'archive ouverte pluridisciplinaire HAL, est destinée au dépôt et à la diffusion de documents scientifiques de niveau recherche, publiés ou non, émanant des établissements d'enseignement et de recherche français ou étrangers, des laboratoires publics ou privés. 


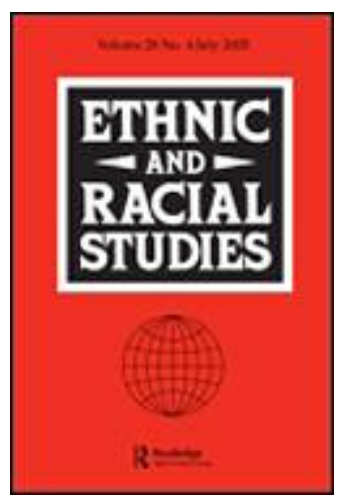

Social Capital and Voting Participation of Immigrants and Minorities in Canada

\begin{tabular}{|r|l|}
\hline Journal: & Ethnic and Racial Studies \\
\hline Manuscript ID: & RERS-2008-0005.R1 \\
\hline Manuscript Type: & Original Manuscript \\
\hline Keywords: & $\begin{array}{l}\text { Electoral behaviour, Ethnic Minorities, Immigrants, Social Capital, } \\
\text { Political Participation, Voting participation }\end{array}$ \\
\hline \multicolumn{2}{|l}{} \\
\hline
\end{tabular}

\section{5) ScholarONE" \\ Manuscript Central}




\title{
Social Capital and Voting Participation of Immigrants and Minorities in Canada ${ }^{1}$
}

\begin{abstract}
Using the social capital literature as a base, we explore the issue of interaction with others on voter participation with particular emphasis on exploring the differences between Canadian-born majority, and minority residents.

We use the 2002 wave of the Equality Security Community Survey to explore the relationship between voting and personal characteristics, work characteristics, social capital attributes and ethnic characteristics. We find that the odds of voting are largely a product of socio-demographic and social capital attributes. The impact of immigration and ethnicity is largely overridden. This suggests that it is not the minority attribute that impacts voting. Rather it is age, level of schooling and level of civic engagement which affects the probability of voting, both federal and provincial.
\end{abstract}




\section{Introduction}

One of the core responsibilities in democratic societies is participation in the electoral process. Indeed, Canadian citizenship court judges highlight voting as one of the primary benefits and responsibilities of acquiring citizenship.

In settler societies, such as Canada, because citizenship acquisition is relatively rapid the diversity of potential voters has expanded dramatically over the past half century. ${ }^{2}$ This fact is recognized by Elections Canada which, through its outreach program, attempts to provide electoral information to potential voters in twenty-six heritage as well as 11 Aboriginal languages. Despite the political interest, however, little is known about the voting probabilities of minorities in Canada. Even less understood is the interaction of voter behaviour with aspects of social capital such as trust, belonging, civic awareness and interaction with others.

The goal of this paper is to assess the degree to which there are differences in the probability of voting either federally or provincially between three groups: Canadianborn majority residents, Canadian-born minority residents and permanent immigrants who have attained Canadian citizenship. Our goal is to determine the degree to which differences in voting probabilities are a product of minority or immigrant status as compared to a set of human and social capital attributes. The primary questions we ask are:

- To what extent are there differences in voting participation across the three groups? and; 
- If there are differences, to what extent are they explained by demographic and socio-economic factors, social capital attributes and ethnicity/immigration related factors?

Our data are drawn from the 2002 wave of the Equality Security Community (ESC) survey. We find that formal (often bridging) interactions (membership in organizations and attending religious services) as well as sense of belonging at a local level and civic awareness are strong predictors of voting. Informal (generally bonding) interactions (talking to friends and neighbours) do not have a significant effect on the degree to which people vote.

While personal characteristics (age, sex, education, etc) and social capital attributes explain a great deal of voting behaviour, minority status (ethnic origin, immigrant status and language) does not. With few exceptions, after these controls are included in the model, minorities display the same voting probabilities as majority members.

\section{Determinants of voting behaviour of immigrant and ethnic minorities}

Studies that include an analysis of the voting behaviour of minorities are more numerous in Europe than in North America, this is probably because voting rights in local elections are often extended to all permanent residents rather than just citizens.

Several papers have looked at the impact of social capital attributes measured by trust in government and use of media on the probability of voting. In Denmark, for example, Togeby (1999) looks at collective mobilisation as a determinant of voting 
behaviour. She argues that the Danish local election system creates opportunities for mobilisation through a proportional elections system which incorporates special rules for seat allocation. This in turn results in higher voter participation for immigrants. In Sweden, however, higher concentrations of immigrant groups have led to collective demobilization and rather low voting participation among immigrants (Togeby 1999).

Fennema and Tillie (1999) look at voting by Turks, Moroccans, Surinamese and Antilleans in Amsterdam, focussing in particular on the relationship between voting and trust in institutions. They find that civic engagement and trust in institutions are powerful determinants of voter participation. They argue that low trust in government may lead to lower voting participation and when participation is very low a legitimacy problem comes into play. Theiss-Morse and Hibbing (2005) however argue that increased political participation is non-linear with increased political trust and that those with high trust feel less need to participate.

A number of scholars tested the Fennema and Tillie hypothesis which suggests that differences in the political participation of ethnic minorities are linked to differences in the level of 'civic community'. By civic community Fennema and Tillie (1999) mean the amount of within-group social capital, measured by participation in ethnic associations. It is hypothesized that participation results in higher levels of social capital which in turn result in higher levels of social trust (see also Jacobs \& Tillie 2004).

Berger et al (2004) test this idea in Germany and find a positive relationship between participation in mainstream organizations and integration. But the relationship between participation in ethnic organizations and interaction is not as clear. Migrants seem to be in general more politically active when participating in ethnic organisations, 
but when it comes to involvement in German politics, participation rates are about the same for members as for non-members.

Togeby (2004) used a sample of second generation minorities in Denmark and found different effects on formal (voting) and informal political participation between ethnic groups. Participation in ethnic associations has a strong effect on informal political participation among Pakistanis, but not on voting participation. For Turks, the effects were weaker, and for Yugoslavs they were non-existent. Participation in organizations did not result in higher levels of social trust for any of the three groups.

Jacobs et al (2004) examined political participation of Moroccans and Turks living in Belgium. They found that Turks exhibited high scores on a number of indicators of 'ethnic civic community', whereas Moroccans scored higher in political involvement. However they did not find a strong relationship between membership in ethnic associations and political involvement.

Messina (2006) compared voter participation rates of citizens and non-citizens in a number of European countries and concluded that obtaining citizenship and number of years spent in the host country are both positively related to higher rates of electoral participation. At the same time different minorities and immigrant groups show very different voting rates. He argues that differences can be explained by differential rates of alienation and apathy related to the level of integration by minorities and immigrants. Messina also concludes that the increase of refugee migration has resulted in a situation where immigrants are more concerned with the politics of the country of origin than with politics in the host country. 
Research in Canada and the United States has tended to concentrate on the relationship between human capital and voting. Research on the relationship between social capital and voting has remained relatively nascent.

DeSipio (1996) for example, shows that education and age are powerful correlates of voting (see also Bass and Casper 2001). This is reiterated by Tuckel and Meisel (1994) who look at voting by European minorities living in the United States. They argue that demographic and socioeconomic factors, such as age, education and labour force characteristics are the dominant factors in explaining voting probabilities. However, Ramakrishnan and Espenshade (2001) using multiple years of the CPS to measure the probability of voting based on minority status and find that minorities are substantially less likely to vote in elections as compared to native-born majority residents. Further, these differences are not always reduced from one generation to another. Bass and Casper (2001) using 1996 CPS data find similar results, concluding that generally age and education are positively correlated with voting as is length of residence for immigrants. Finally Lien (2004) finds that Asians born in the US are less likely to vote than natives.

Ramakrishnan and Espenshade (2001) extend the model of immigrant voting behaviour by adding controls for generation, language proficiency (English), duration of stay, ethnic residential concentration and political socialization in the home country. They find that the pattern of voting participation differs by ethnic group. Except for Black and Asian-American immigrants, a longer stay in the US increases the probability of voting. Being an immigrant from a repressive regime has a weak negative effect on voting participation. Language proficiency, as measured by the presence of Spanish- 
language ballots and proximity to co-ethnics (measured at a state level) did not have a strong effect on the probability of voting. They did find, however that the "political culture" in a state influences voting behaviour.

Cho (1999) uses a 1984 survey of California residents to measure the effect of socioeconomic variables on voting behaviour of four minority groups (Latino, Black, Asian and non-Hispanic white). She argues that socioeconomic characteristics merely provide the skills for political activity. Socialization determines the degree to which these skills are used. Given that immigrant groups in particular have different socialization experiences, their pattern of voting will differ despite having similar socio-demographic characteristics. Thus, while education had little impact for Asian-Americans, it had twice the impact for Latinos.

Few studies on the determinants of voting behaviour of immigrants and ethnic minorities have been conducted in Canada. ${ }^{3}$ Instead, the focus has been on broader political participation issues such as citizenship acquisition and representation of foreign born in parliament (see for example Bloemraad 2006; DeVoretz and Pivnenko 2006). Chui, et al (1991) used the 1984 Canadian Election Survey to measure seven attributes of electoral participation (including voting) using Multiple Classification Analysis. They found that while immigrants did participate less, their offspring either had the same or higher participation rates than was the case for 'deeply rooted Canadians'. A more recent study by Jedwab (2006) uses the 2002 Ethnic Diversity Survey to conduct a tabular analysis of voting by minorities in Canada. He found that increased ethnic belonging and ethnic identity had no negative impact on voting 
participation and that sense of belonging to Canada correlated with higher voter participation (see also White et al 2006).

Putnam (1993, 1995 and 2000) has argued that increased social capital should be important for a wide variety of issues including political participation. However little work has been done in the area. In Canada, Nakhaie (2006) used the 2001 National Survey of Giving, Volunteering and Participation to measure the impact of social capital on voter participation. He found that formal social capital attributes (volunteering, religious participation) as well as 'community rootedness' (belonging) are associated with higher voting probabilities. He was unable, however to test for the impact of minority status.

Our study enters the fray by building on past work to look at human capital and social capital attributes and the probability of voting based on minority and immigrant status. We operationalise social capital broadly examining issues of trust, sense of belonging, and civic awareness - reading current events in newspapers and watching the news on television. In addition we assess the extent to which voting is affected by informal interaction (talking to friends and neighbours) and formal interaction (being a member of a recreational organisation, attending religious services and volunteering).

\section{Data and Method}

The Data:

Our data are drawn from the 2002 wave of the Equality, Community Security Survey. ${ }^{4}$ This survey contains a broad range of questions on social capital economic attributes, and voting behaviour as well as detailed demographic characteristics such as ethnic origin and 
immigrant status. It is particularly useful for studies of ethnicity because the survey includes an oversample of individuals living in census tracts in Montreal, Toronto, and Vancouver with large visible minority populations. Thus, the total number of visible minorities---defined as people of non-European non-Aboriginal origin---is substantial for a survey of this size. The survey has 5654 respondents, 604 of whom are members of a visible minority.

We made a number of selections. Voting in federal and provincial elections in Canada requires citizenship, so only citizens (including naturalized) are included in the sample. As well, voters have to be 18 years of age or older, at the time of the election, so we also made a selection on age. After selection for citizenship and voting age, we are left with 4,662 respondents, 536 of whom are immigrants. ${ }^{5}$

\section{Variable treatment:}

Along with our variables identifying minority and immigrant status, we include demographic characteristics, socio-economic characteristics and social capital characteristics. The demographic characteristics consist of 4 dummy variable sets: gender (male and female), age (6 dummies), marital status ( 5 dummies) and presence of children (yes or no). The socioeconomic variables include schooling (8 dummies) and employment status (8 dummies) (Appendix A has a full description of the variables used).

We test 10 social capital characteristics which measure different facets of social capital. The first three measure trust in government and the sense of belonging felt by the respondent. Trust in government (either provincial or federal depending on whether we 
are testing for federal or provincial voting) is scaled from 1 (trust the government to do the wrong thing most of the time) to 4 (trust the government to do the right thing most of the time). ${ }^{6}$ The two sense of belonging questions tap the degree to which the respondent feels he or she belongs at a national level and a neighbourhood level. The two variables are scaled from 1 to 10 , where 1 means the respondent does not feel he belongs and 10 means the respondent feels he belongs completely.

The next two variables tap civic awareness using questions that ask about the frequency of either reading about local news in the paper or watching the news on television. Awareness is measured on a seven point scale where 1 means the respondent never reads or watches the news and 7 means that the respondent reads or watches the news ever day.

The next two variables are related to informal interaction with either friends or family and are scaled from 1 to 7 . The last three variables tap formal interaction. Frequency of attendance at religious services (scaled from 1-7) membership in voluntary organizations (dichotomous) and membership in organized recreational groups (dichotomous) measure the degree to which the respondent is involved in formal, organized interaction with others.

In order to facilitate comparison across social capital attributes, variables that are scaled (trust in government, sense of belonging, reading or watching the news, seeing friends and neighbours, and attending religious services) are standardized on a zscore so that they have a mean of zero and a range from about -4 to +4 . Being a member of a volunteer organization or a recreational group remain as nominal (dummy) variables. 
Minority status variables include age at immigration (6 dummy variables), language spoken at home (either English/French or other), and ethnic origin. Ethnicity is divided into 3 broad categories: Majority (British/French/Canadian), European origins and non-European origin groups (Asian, Latin American and African origins). The data also allow us to provide results for a small number of individual ethnic groups. ${ }^{7}$

We include one contextual variable in all the models. The natural log of the city population for the year 2001 (the closest census year available) for each respondent is included because several authors have suggested that city size is an important variable in determining social capital attributes - the larger the city, the lower the overall level of social capital in the city (see Putnam 2007).

\section{Analysis}

Our analysis is divided into two main parts. The first explores the issue using descriptive statistics on voting behaviour. The second tests three models using probit regressions to measure the odds of voting in the federal and provincial election.

\section{Descriptive results: Basic findings for voting participation}

The descriptive statistics in table $1 \mathrm{~A}$ in the appendix provide an initial picture of the differences in voting participation by demographic, socio-economic, ethnic and social capital characteristics included in the model.

In the table of descriptives, we see a curvilinear relationship between trust in government and voting behaviour in both the federal or provincial elections. Those who almost never trust government are less likely to vote than those who have some trust. 
Those who trust most of the time have an even higher voting rate. However those that almost always trust government to do the right thing most of the time have a lower rate of voting participation than those with lower levels of trust.

A higher sense of belonging correlates with increasing voting participation at both the federal and provincial level. This is especially true for belonging at the neighbourhood level where the difference between those that do not feel they belong in the neighbourhood and those that do is 26 per cent. Voting participation is also positively correlated with current affairs awareness. The more one reads the paper or watches the news on television, the more likely it is that they will vote.

Informal interaction is measured by seeing friends and talking to neighbours. The descriptive statistics in Table la suggest that those who never see friends or talk to neighbours have a lower rate of voting both federally and provincially. However those who do see friends or talk to neighbours, regardless of frequency, do display higher rates of voting.

Formal interaction is measured by responses to three questions: attending religious services, being a member of a voluntary group or being a member of an organized recreational group. Attending religious services is positively correlated with voting. The more one attends religious services, the higher the likelihood of voting. Both being a voluntary member of an organisation and being a member of a recreational group also yields higher voting participation in both provincial and federal elections. This result is in line with earlier studies that suggest individuals that higher degrees of social activity have a higher political participation, including voting (Egmond van, de Graaf and van der Eijk 1998). 
Ethnocultural origin is tapped through variables asking about immigrant status, age at immigration, home language, religion and ethnic origin. Immigrant status does not appear to make a huge difference in the probability of voting. About $80 \%$ of the Canadian-born population and immigrants who arrives after age 15 say they voted in the last federal election. However, immigrants who arrived before the age of 15, are less likely to vote that those who arrived later in life. Respondents claiming no religion and those claiming Islam as a religion have a lower voting participation rate as compared to people claiming other religions. Protestants and Catholics in particular have very high rates of voting ( $88 \%$ and $84 \%$ respectively voted in the last federal election). Speaking English or French at home (as compared to another language) is also correlated with higher voter participation. Finally, the table shows that individuals who consider themselves to be part of a majority ethnic origin (British, French or Canadian) and those with European backgrounds have a higher voting participation rate than those who consider themselves to be members of a visible minority.

A more detailed ethnic group categorisation shows that individuals with Black, Chinese and East and Southeast Asian background have a lower voting participation rate. Only two-thirds of Black or Chinese and 70\% of East and Southeast Asian respondents voted in the last election. These results accord with the finding of Ramakrishnan and Espenshade (2001).

\section{Probits}

Overall, analysis of the descriptive statistics suggests that with the exception of seeing friends, social capital, both formal and informal has a positive impact on voter 
participation. Social background, based on religion, ethnic origin and immigrant status also has an impact. However in this case, membership in a minority group is associated with lower voter participation rates.

In this section we run four sets of probit regressions ${ }^{8}$ (Tables 1-4) in order to measure the odds of voting in the 2002 federal or most recent provincial election. The first model includes only demographic and socio-economic characteristics (not including ethnic and immigrant characteristics). The second model adds ten social capital variables. The third model includes all the previous variables as well as a number of ethnicity markers such as religion, age at immigration, home language and ethnicity. In order to understand the relationship between ethnicity and social capital, this model interacts the social capital variables with membership in the ethnic categories. The fourth model breaks out the broad ethnic categories into 13 discrete groups in order to see if the effects found in previous models hold true for individual ethnic groups.

\section{Table 1}

\section{Model 1: Demographics and socio-economic variables}

Previous research has suggested that age and schooling are powerful predictors in determining the degree to which people vote (see DeSipio 1996; Bass and Casper 2001; and Tuckel and Meisel 1994). Our analysis seconds these findings. Seniors are far more likely to vote as compared to younger age groups. The odds of voting for people in their sixties and seventies are almost four time that of people who are less than 30 years old. People who are married or divorced have higher odds of voting than those who are single, 
separated or widowed; however having children has no impact on voting patterns. Gender has no impact on the odds of voting.

City size also matters. The larger the city, the lower the odds of voting (odds ratio of 0.96 for every $1 \log$ unit of city size). Education has a strong positive effect. People with a bachelors degree have about twice the odds of voting compared to people who have less than high school. Working for pay increases the odds of voting as compared to being self-employed by about a quarter for federal elections, but has no impact for provincial elections. Being disabled decreases the odds of voting by about a third in federal elections. Students have lower odds of voting in provincial elections compared to people engaged in other types of economic activity, however being retired, unemployed, or a homemaker, has no additional impact on the odds of voting.

We note that the demographic and socio-economic coefficients are remarkably stable as we move from one regression to another, maintaining roughly the same direction, magnitude and significance from one model to another. We are thus comfortable simplifying the presentation of results by omitting the socio-demographic variables from tables 2 and $3 .^{9}$

\section{Table 2}

\section{Model 2: Social Capital}

Model 2 adds the ten social capital variables to the analysis. As stated previously, this model includes all the socio-demographic variables included in Table 1, as well as the 
socio-capital variables shown in Table 2. Looking first the results for the federal election we see that six of the eight standardized variables have significant positive effects. The most powerful effects are religious attendance (1.14), and belonging at the neighbourhood level (1.09). Trust in the federal government, and current affairs awareness (reading and watching the news regularly) also have positive effects (ranging from 1.07 to 1.10 ). However belonging at the Canada level, seeing friends and talking to neighbours has no significant impact on voting. Volunteering has no effect on voting federally; however being a member of a recreational group does have an effect (1.15).

Results for voting in provincial elections display some interesting differences. Trust in government, watching the news, attending religious services and being a member of a recreational group has about the same impact on voting as was seen federally. Sense of belonging at a Canada level, has a strong and significant negative impact on provincial voting (0.94 for every standard deviation increase). Being a volunteer has a strong positive impact (1.18).

Overall the findings suggest that formal organized interaction such as taking part in voluntary organizations, membership in recreational groups and attending religious services has a positive impact on voting. Respondents who attend religious services weekly display more than twice the odds of voting in a federal election compared to people who do not attend religious services. However informal interaction such as seeing friends and talking to neighbours has no impact on voting. Sense of belonging in the neighbourhood has a positive impact on voting, but sense of belonging at a national level has a negative impact on both provincial and federal voting. 
Table 3

\section{Model 3: Ethnicity, Religion}

Model 3 adds controls for immigration and religion and includes interactions between ethnicity and the social capital variables. Looking first at the results for the federal election we see that as compared to people who claim no religion, Protestants, and those in the 'Other Judeo-Christian' group are more likely to vote (the odds increase by 1.2 and 1.6 respectively). However Evangelical Protestants, Catholics, Muslims and Sikhs and Hindus (other eastern) have about the same odds of voting as people claiming no religion. Immigrants who arrive in their twenties have lower odds of voting federally, but other immigrant groups have about the same odds of voting as people born in Canada.

The effects of the social capital variables are similar to those seen in model 2, however there are some interaction effects by ethnic origin. Specifically, watching the news has a positive effect, however the interaction term with ethnic origin displays lower odds of voting. Thus the interaction of visible minority and watching the news has a significant odds ratio of .82 . This suggests that visible minorities who watch the news reap a lower 'voting benefit' compared to majority members who watch the news or European minorities. The only other significant interaction is with recreational activity and European. While recreational activity has a positive impact on the odds of voting (1.22) being European and being involved in recreational activity displays lower odds of voting (.67). However, there is no significant interaction for visible minorities and being a member of a recreational group. 
The impact of religiosity is measured through attendance at religious ceremonies. As with the previous model, the more frequent the attendance, the more likely the person is to vote. However there is no additional impact by ethnic origin. Rather it appears that it is the attendance that matters, not the religion or the ethnic origin of the respondent.

Results for voting provincially are similar in spirit with the social capital findings that were significant in model 2 maintaining roughly the same magnitude and significance. With the exception of one variable, there are no significant interaction effects. Trust in the provincial government interacted with ethnicity lowers the odds of voting compared to majority members ( .89 for Europeans and .80 for visible minorities).

\section{Model 4: Detailed ethnicity}

Table 4 shows the odds of voting for selected ethnic origins. All previous variables are included in the model, but for the sake of simplicity, we only show the coefficients for the ethnic origins. Because the model includes age at immigration these coefficients should be interpreted as the controlled effects of being Canadian-born minorities.

The results from Table 4 suggest that with two exceptions, after controlling for socio-demographic and social capital attributes most minorities have about the same odds of voting as British origin respondents. French origin respondents have significantly higher odds of voting. Being French increases the odds of voting by about a quarter. Being Chinese however, reduces the odds of voting in a federal election by about a quarter. 


\section{Table 4}

The odds of voting in a provincial election are about the same for all groups.

\section{Concluding discussion}

In this paper we examine the voting behaviour of immigrants and ethnic minorities in Canada using the 2002 wave of the Equality Security Community (ESC) survey. Using probit regression techniques, we measure the odds of voting in the 2000 Federal election and the most recent provincial election prior to 2001 . We find that overall, there are few differences between majority and minority members and their odds of voting after socioeconomic and social capital attributes have been included in the model. In other words, it is not minority status driving voter turnout. Rather it is largely the combination of demographic, socio-economic and social capital attributes that explain voter turnout.

As suggested by Putnam (2007) the size of the city of residence is an important and negative determinant in the development of social capital. In support of this, we found that the larger the city, the lower the odds of voting. This is consistent across all models, and city size is always significant.

As with Bass and Casper (2001), Tuckel and Meisel (1994) and White et al (2006) we found that increased age and higher education have a strong positive effect on voting behaviour. Being married increases the odds of voting and those who work for pay are more likely to vote than those who do not. Gender did not have a significant impact on voting. 
After controlling for social capital and socio-economic attributes, we did not find any significant differences by ethnic origin. This is similar to that found by Jedwab (2006) but counter to Ramakrishnan and Espanshade (2001) and Messina (2006).

However as with Chui, et al (1991), we found that immigrants who arrived in their 20s or 40s were less likely to vote than those who arrived at an earlier age, or those who were born in Canada.

Overall, religious affiliation does not make a difference in voting. Only Protestants displayed higher odds of voting, as compared to people claiming no religion. Rather it is the formal activity of attendance at religious services that increases voter turnout.

Probit regressions revealed that with the exception of informal interaction, social capital attributes were powerful determinants of voter turnout. A high sense of belonging at a local (neighbourhood) level increased the odds of voting in both provincial and federal elections. However, in contrast to Jedwab (2006) we found that belonging at the national level, has no impact on federal voting. Indeed, a high sense of belonging at the provincial level decreases the odds of voting in a provincial election.

Trust in government (whether provincial or federal) is important. As compared to Theiss-Morse and Hibbing (2005) we found that higher levels of trust corresponded to higher voter participation. Related to this, awareness of issues (either through reading or watching the news) is also correlated with higher voter turnout. These results are also in line with Fennema and Tillie (1999) and indicate that higher civic engagement increase political participation. Thus maintaining a high level of trust appears critical to electoral participation. Sense of belonging at a national or provincial level has no impact on 
voting. However sense of belonging at a local level has a strong impact - the odds of voting for people with a high sense of neighbourhood belonging are almost double those of someone people with a low sense of belonging. Thus, strategies to encourage voting should seriously consider concentrating on approaches which focus on the importance of voting as a local issue.

People who access the news (either in print or on television) are more likely to vote than those who do not, regardless of minority status. This suggests that the ethnic media sources may be every bit as good at encouraging voter participation as mainstream news sources, and could therefore be used as a vehicle for increasing participation amongst minorities.

The impact of formal and informal activity on voting depends on the activity itself. Bonding activity, such as talking to friends and neighbours has no impact on voter turnout. However, attending religious services, a broadly bonding activity, has a strong positive impact on voting. Being a member of a recreational group, which is potentially a bridging activity, is associated with higher odds of voting in both federal and provincial elections and seconds the results of Berger et al (2004). However voluntarism, another potentially bridging activity is only associated with higher odds of voting at the provincial level.

In conclusion, it appears that social capital matters for voting. High levels of formal interaction, trust and belonging are clearly associated with higher odds of voting. Indeed, the combination of socio-demographic and social capital attributes largely overrides the impact of immigration and ethnicity, suggesting that it is not the minority 
attribute that impacts voting. Rather it is age, level of schooling formal interaction and level of civic engagement which effects voting, both federal and provincial. 


\section{References}

BASS, LORETTA E. AND CASPER, LYNNE M 2001 'Impacting the Political Landscape: Who Registers and Votes among Naturalized Americans?', Political Behavior, vol. 23, no. 2.

\section{BERGER, MARIA, GALONSKA, CHRISTIAN AND KOOPMANS, RUUD 2004 'Political Integration by a Detour? Ethnic Communities and Social Capital of Migrants in Berlin', Journal of Ethnic and Migration Studies, vol. 30, no. 3.}
BLOEMRAAD, IRENE 2006 Becoming a Citizen, Incorporating Immigrants and Refugees in the United States and Canada, Berkeley: University of California press.
CHO, TAM WENDY K 1999 'Naturalization, Socialization, Participation: Immigrants and (Non-) Voting', The Journal of Politics, vol. 61, no. 4.
CHUI, TINA., CURTIS, JOHN AND LAMBERT, RON 1991 'Immigrant background and political participation: examining generational patterns', Canadian Journal of Sociology, vol. 16, no. 4.
DEVORETZ, DON AND PIVNENKO, SERGIY 2006 'The Economic Causes and Consequences of Canadian Citizenship' Journal of International Migration and Integration, vol. 6. no. 3/4.


DESIPIO, LOUIS 1996 'Making citizens or good citizens? Naturalization as predictor of organizational and political behavior among Latino immigrants' Hispanic Journal of Behavior Sciences, vol.18.

DIEHL, CLAUDIA AND BLOHM, MICHAEL 2001 'Apathy, adaptation or ethnic mobilization? On the attitudes of a politically excluded group', Journal of Ethnic and Migration Studies, vol. 27, no. 3.

EGMOND VAN MARCEL, DE GRAAF NAN D. AND VAN DER EIJK, CEES 1998 'Electoral participation in the Netherlands: Individual and contextual influences', European Journal of Political Research, vol. 34.

FENNEMA, MEINDERT AND TILLIE, JEAN 1999 'Political participation and political trust in Amsterdam: civic communities and ethnic networks' Journal of Ethnic and Migration Studies, vol. 25 no. 4.

JACOBS, DIRK AND TILLIE, JEAN 2004 'Introduction: Social Capital and Political Integration of Migrants', Journal of Ethnic and Migration Studies, vol. 30, no. 3.

JACOBS, DIRK, PHALET, KAREN AND SWYNGEDOUW, MARK 2004

'Associational membership and political involvement among ethnic minority groups in Brussels', Journal of Ethnic and Migration Studies, vol. 30, no. 3. 
JEDWAB, JACK 2006 'The "Roots" of Immigrant and Ethnic Voter Participation in Canada', Electoral Insight, Electoral Participation of Ethnocultural Communities, vol. 8 , no. 2 .

LIEN, PEI-TE 2004 ‘Asian Americans and Voting Participation: Comparing Racial and Ethnic Differences in Recent U.S. Elections', International Migration Review, vol. 38 , no. 2 .

MESSINA, ANTHONY. M 2006 'The Political Incorporation of Immigrants in Europe: Trends and Implications', The Migration Reader, Exploring Politics and Policies, (Eds. Messina. A. M. and Lahav, G.), Boulder/London: Lynne Rienner Publishers.

NAKHAIE, REZA M 2006 'Electoral Participation in Municipal, Provincial and Federal Elections in Canada', Canadian Journal of Political Science, vol. 39, no 2.

PUTNAM, ROBERT D 1993 Making Democracy Work: Civic Traditions in Modern Italy, Princeton: Princeton University press.

PUTNAM, ROBERT D 1995 'Bowling Alone, America’s declining Social Capital', The Journal of Democracy, vol. 6, no.1. 
PUTNAM, ROBERT D 2000 Bowling alone: The collapse and Revival of American Community. New York: Simon and Schuster.

PUTNAM, ROBERT D 2007 'E Pluribus Unum: Diversity and Community in the Twenty-first Century The 2006 Johan Skytte Prize Lecture’, Scandinavian Political Studies, vol. 30, no. 2.

RAMAKRISHNAN, S. KARTHICK AND ESPENSHADE, THOMAS 2001 'Immigrant Incorporation and Political Participation in the United States', International Migration Review, vol. 35, no. 3.

THEISS-MORSE, ELIZABETH AND HIBBING, JOHN, R 2005 'Citizenship and Civic Engagement' Annual Review of Political Science.

TOGEBY, LISE 1999 'Migrants at the polls: an analysis of immigrant and refugee participation in Danish local elections', Journal of Ethnic and Migration Studies, vol. 25 , no. 4 .

TOGEBY, LISE 2004 'It Depends... How Organisational Participation Affects Political Participation and Social Trust Among Second-Generation Immigrants in Denmark', Journal of Ethnic and Migration Studies, vol. 30, no. 3. 
TUCKEL, PETER AND MAISEL, RICHARD 1994 'Voter Turnout among Europeans Immigrants to the United states', Journal of Interdisciplinary History, vol. 24, no. 3.

WHITE, STEPHEN. ET AL 2006 'Making Up for Lost Time, Immigrant Voter Turnout in Canada' in Electoral Insight, Electoral Participation of Ethnocultural Communities, vol. 8, no. 2. 


\begin{abstract}
Appendix
This appendix describes the variables used in the analysis and the basic descriptive statistics.

Voting (dependent variable):
\end{abstract}

Did you vote in the last FEDERAL election in $2000 ?$

1 yes 5 no d don't know $r$ refused

Did you vote in the last Provincial election?

1 yes 5 no d don't know $r$ refused

Respondent's gender:

Male

Female

Age:

In what year were you born?

Marital Status:

URL: http://mc.manuscriptcentral.com/rers ethnic@surrey.ac.uk 


\author{
Are you presently: \\ married \\ living with a partner \\ separated \\ divorced \\ widowed \\ never been married \\ Presence of Children:
}

\begin{abstract}
How many children live with you (Does this child currently live with you) for four or more days a week?

no/none

yes/1-12 children
\end{abstract}

What is the highest level of education that you have completed?

Lower or Some elementary school

Some secondary

High school

Some technical, community college, CEGEP, College Classique

Completed technical, community college, CEGEP, College Classique 


\author{
Some university (includes obtained certificate but not a degree) \\ Bachelor's Degree \\ Master's degree / Doctorate
}

Economic Status:

\author{
Are you currently self employed, working for pay, retired, unemployed or looking \\ for work, a student, a homemaker, or something else? \\ self employed (with or without employees) \\ working for pay (full or part time ) \\ retired \\ unemployed/looking for work \\ student \\ homemaker \\ disabled \\ Immigrant Status:
}

Age at Immigration (calculated from age and year of immigration)

Citizenship (Selection variable)

Are you a Canadian Citizen? 
yes or no

\author{
Broad Ethnicity
}

To what ethnic or cultural group do you belong?

Recoded to British/French/Canadian; European; Visible Minority

Home language at home

What language do you usually speak at home?

English/French

other

Religion:

Please tell me what is your religion, if you have one?

Recoded to:

None, Protestant; Evangelical Protestant; Catholic; Other Judeo-Christian;

Muslim; Other Eastern; Other.

Contact Friends and Neighbours:

How often do you see close friends? 
And how often do you talk with neighbours?

1 every day

2 several times a week

3 at least once a week

4 at least once a month

5 several times a year

6 less often (includes never)

0 no close friends

\section{Trust in Government:}

How much do you trust the government in Ottawa to do what is right?

How much do you trust the government in [R's PROVINCE] to do what is right?

1 almost always (includes always)

3 most of the time

5 some of the time

7 almost never (includes never)

Member of a voluntary organization (1 if yes to any of the following):

I am going to read a list of different types of groups and organizations. For each of them, I would like you to tell me how many groups of that type, if any, you are a member of... 
How many service clubs, such as the Lions Club or Meals on Wheels, do you belong to?

How many organizations active on political issues, such as the environment or taxpayers' rights, do you belong to?

How many youth-oriented groups, such as Girl Guides or Minor Hockey, have you volunteered time to in the last 12 months?

How about organizations providing cultural services to the public, such as a museum or music festival.

How about organizations that help people, such as the Cancer Society or a food bank?

How many organizations connected with your own nationality or ethnic or racial group are you a member of?

How many groups directly associated with your place of worship, such as a charitable group, are you a member of?

Do you belong to or volunteer for any other groups or organizations that we have NOT asked about?

\section{Recreational member (1 if greater than 0)}

How many recreational groups, such as sports leagues or clubs, music or hobby clubs, or exercise classes are you involved in?

\section{Current affairs awareness:}


In a typical week, how many days do you read a daily newspaper / watch the news on television?

0 none $1-7$ code number of days

Belonging:

Please tell me how much you feel that you belong to each of the following places.

Using a scale from 1 to 10 where 1 means you feel like you do not belong at all and 10 means you feel that you belong completely, what number best describes how you feel about Canada? Province? Neighbourhood?

1-10 enter number

Attendance at religious services

How often do you attend religious services, not including weddings and funerals? nearly every week (includes every week or more often)

2-3 times a month

about once a month

several times a year

once or twice a year

less than once a year

never 
Table 1

Results from probit regressions showing the odds of voting in a federal or provincial election by personal and socio-economic characteristics

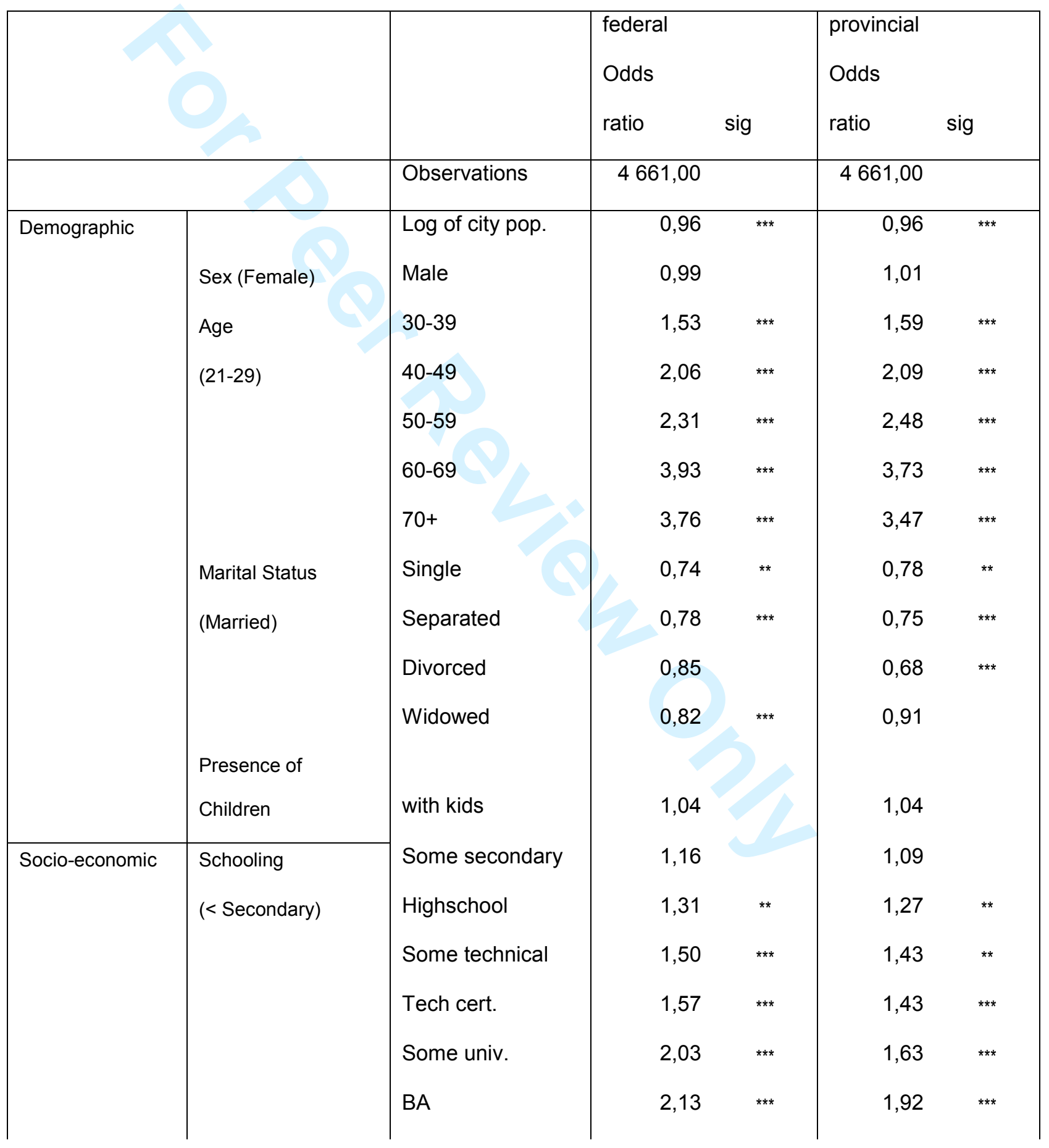




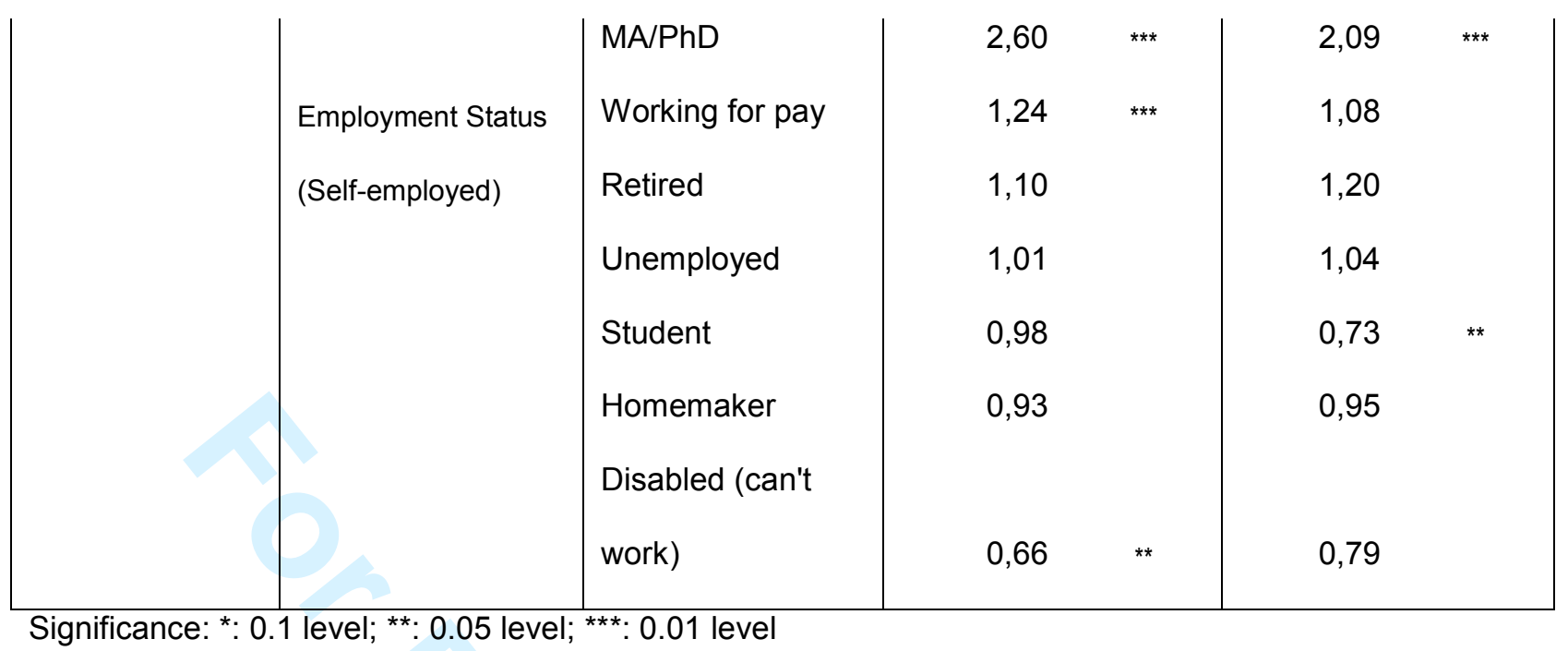


Table 2

Selected results from probit regressions showing the odds of voting by social capital attributes, controlling for personal characteristics, and socio-economic characteristics

\begin{tabular}{|c|c|c|c|c|c|}
\hline & & $\begin{array}{l}\text { federal } \\
\text { Odds ratio }\end{array}$ & sig & $\begin{array}{l}\text { provincial } \\
\text { Odds ratio }\end{array}$ & sig \\
\hline & Observations & 4489,00 & & 4489,00 & \\
\hline \multirow[t]{8}{*}{ Standardized } & Trust federal govt & 1,08 & 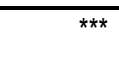 & 1,06 & ** \\
\hline & Belonging: Canada & 1,04 & & 0,95 & ** \\
\hline & Belonging: neighbourhood & 1,09 & *** & 1,15 & *** \\
\hline & Read news & 1,10 & *** & 1,04 & ** \\
\hline & Watch news & 1,07 & $* * *$ & 1,08 & *** \\
\hline & See friends & 0,99 & & 1,01 & \\
\hline & See neighbours & 1,01 & & 0,98 & \\
\hline & Attend religious services & 1,14 & $* * *$ & 1,11 & *** \\
\hline Don't volunteer & Volunteer & 1,07 & & 1,18 & *** \\
\hline Not a member & Recreation org & 1,15 & $* * *$ & 1,13 & $* * *$ \\
\hline
\end{tabular}

Significance: *: 0.1 level; ${ }^{* *}$ : 0.05 level; ${ }^{* * *}: 0.01$ level

Note:

Age, sex, marital status, presence of children and education are also included it the model 
Table 3

Selected results from probit regressions showing the odds of voting by origin and social capital attributes, controlling for personal characteristics, and socio-economic characteristics

\begin{tabular}{|c|c|c|c|c|c|}
\hline & & $\begin{array}{l}\text { federal } \\
\text { Odds ratio }\end{array}$ & sig & $\begin{array}{l}\text { provincial } \\
\text { Odds ratio }\end{array}$ & sig \\
\hline & Observations & 4200,00 & & 4200,00 & \\
\hline Religion (no religion) & $\begin{array}{l}\text { Protestant } \\
\text { Evangelical Protestant } \\
\text { Catholic } \\
\text { Other Judeo-Christian } \\
\text { Muslim } \\
\text { Other eastern } \\
\text { Other religion }\end{array}$ & $\begin{array}{l}1,20 \\
0,92 \\
1,10 \\
1,60 \\
1,00 \\
1,23 \\
0,65\end{array}$ & * & $\begin{array}{l}, 01 \\
0,81 \\
1,00 \\
1,04 \\
0,92 \\
1,08 \\
0,73\end{array}$ & $\begin{array}{l}\text { ** } \\
\\
\\
* \\
*\end{array}$ \\
\hline $\begin{array}{l}\text { Age at (born in Canada) } \\
\text { Immigration }\end{array}$ & $\begin{array}{l}\text { Immigrated < } 15 \\
\text { Immigrated } 15-19 \\
\text { Immigrated } 20-29 \\
\text { Immigrated 30-39 } \\
\text { Immigrated 40+ }\end{array}$ & $\begin{array}{l}1,09 \\
1,18 \\
0,74 \\
0,74 \\
0,59\end{array}$ & ** & $\begin{array}{l}1,02 \\
1,39 \\
0,68 \\
0,78 \\
0,47\end{array}$ & $* * *$ \\
\hline $\begin{array}{ll}\text { Ethnicity } & \text { (majority }(\mathrm{Br}, \mathrm{Fr}, \\
& \text { Canadian) }\end{array}$ & $\begin{array}{l}\text { European } \\
\text { Visible Minority }\end{array}$ & $\begin{array}{l}0,99 \\
0,85\end{array}$ & & $\begin{array}{l}0,90 \\
1,06\end{array}$ & \\
\hline $\begin{array}{ll} & \text { (English or } \\
\text { Home Lang } & \text { French) }\end{array}$ & $\begin{array}{l}\text { Neither English nor } \\
\text { French }\end{array}$ & 0,89 & & 0,83 & \\
\hline $\begin{array}{l}\text { Social Capital - Ethnicity } \\
\text { Interactions }\end{array}$ & $\begin{array}{l}\text { Trust government } \\
\text { European } \\
\text { Visible Minority } \\
\text { Belonging: Canada }\end{array}$ & $\begin{array}{l}1,11 \\
0,96 \\
0,96 \\
1,01\end{array}$ & $* * \star$ & $\begin{array}{l}1,12 \\
0,90 \\
0,80 \\
0,92\end{array}$ & $\begin{array}{l}* * * \\
* * \\
* *\end{array}$ \\
\hline
\end{tabular}




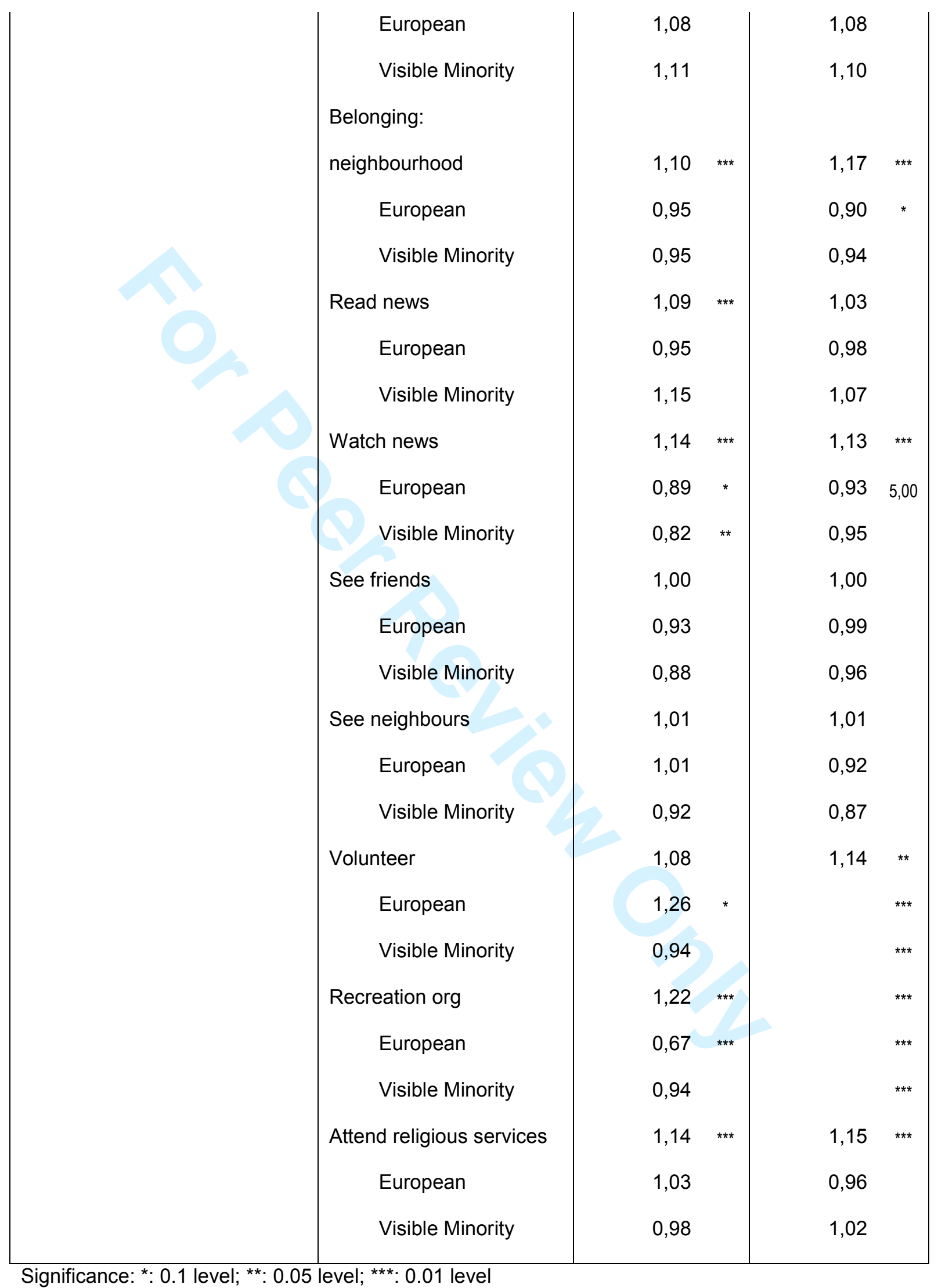


Note: $\quad$ Age, sex, marital status, presence of children and education are also included in the model 
Table 4

Selected results from probit regressions showing the odds of voting by selected ethnic origins compared to British origins, controlling for personal characteristics, socio-economic characteristics and social capital attributes

\begin{tabular}{|l|r|r|}
\hline & Federal & Provincial \\
\hline French & 1,07 & 0,98 \\
N. European & $1,26 \quad{ }^{* *}$ & 1,16 \\
E. European & 1,08 & 1,18 \\
S. European & 1,17 & 1,18 \\
Black & 1,10 & 1,09 \\
S. Asian & 0,75 & 0,70 \\
Chinese & 0,88 & 1,01 \\
E \& SE Asian & 0,78 & 0,83 \\
Other single & 0,91 & 0,77 \\
European w & 1,19 & 0,95 \\
European & & 1,22 \\
British/French w & & \\
other & 1,07 & 0,97 \\
\hline Significance: ${ }^{*}: 0.1$ level; **: 0.05 level; ***: & 0.01 level \\
\hline
\end{tabular}

Note:

Age, sex, marital status, presence of children and education, employment status and social capital attributes are also included in the model 
Table A

Descriptive Statistics showing the percentage of respondents who say they voted in the 2002 federal election, or the last provincial election prior to 2002

\begin{tabular}{|c|c|c|c|c|c|}
\hline & & & Federally & Provincially & count \\
\hline \multicolumn{3}{|l|}{ Total } & $82 \%$ & $77 \%$ & 4888 \\
\hline \multirow[t]{15}{*}{ Demographic } & Sex & Female & $82 \%$ & $77 \%$ & 2658 \\
\hline & & Male & $82 \%$ & $77 \%$ & 2230 \\
\hline & Age & $21-29$ & $61 \%$ & $52 \%$ & 770 \\
\hline & & $30-39$ & $78 \%$ & $74 \%$ & 987 \\
\hline & & $40-49$ & $86 \%$ & $81 \%$ & 1231 \\
\hline & & $50-59$ & $86 \%$ & $84 \%$ & 836 \\
\hline & & $60-69$ & $93 \%$ & $91 \%$ & 507 \\
\hline & & $70+$ & $92 \%$ & $88 \%$ & 557 \\
\hline & Marital Status & married & $85 \%$ & $81 \%$ & 2939 \\
\hline & & separated & $79 \%$ & $75 \%$ & 182 \\
\hline & & divorced & $82 \%$ & $77 \%$ & 373 \\
\hline & & widow & $89 \%$ & $82 \%$ & 361 \\
\hline & & single & $69 \%$ & $65 \%$ & 1016 \\
\hline & Kids in House & no kids & $81 \%$ & $77 \%$ & 2992 \\
\hline & & Kids & $83 \%$ & $78 \%$ & 1896 \\
\hline \multirow[t]{12}{*}{ Socio-economic } & Highest level of schooling & $<=$ elementary & $82 \%$ & $79 \%$ & 218 \\
\hline & & some 2ndardy & $79 \%$ & $75 \%$ & 575 \\
\hline & & Highschool & $78 \%$ & $75 \%$ & 1033 \\
\hline & & some tech & $79 \%$ & $75 \%$ & 337 \\
\hline & & technical & $79 \%$ & $74 \%$ & 894 \\
\hline & & some univ & $84 \%$ & $77 \%$ & 403 \\
\hline & & BA & $85 \%$ & $81 \%$ & 971 \\
\hline & & $\mathrm{MA} / \mathrm{PhD}$ & $91 \%$ & $86 \%$ & 373 \\
\hline & Employment Status & self employed & $81 \%$ & $79 \%$ & 566 \\
\hline & & working for pay (full) & $82 \%$ & $76 \%$ & 2447 \\
\hline & & retired & $91 \%$ & $89 \%$ & 992 \\
\hline & & unemployed & $72 \%$ & $70 \%$ & 251 \\
\hline
\end{tabular}




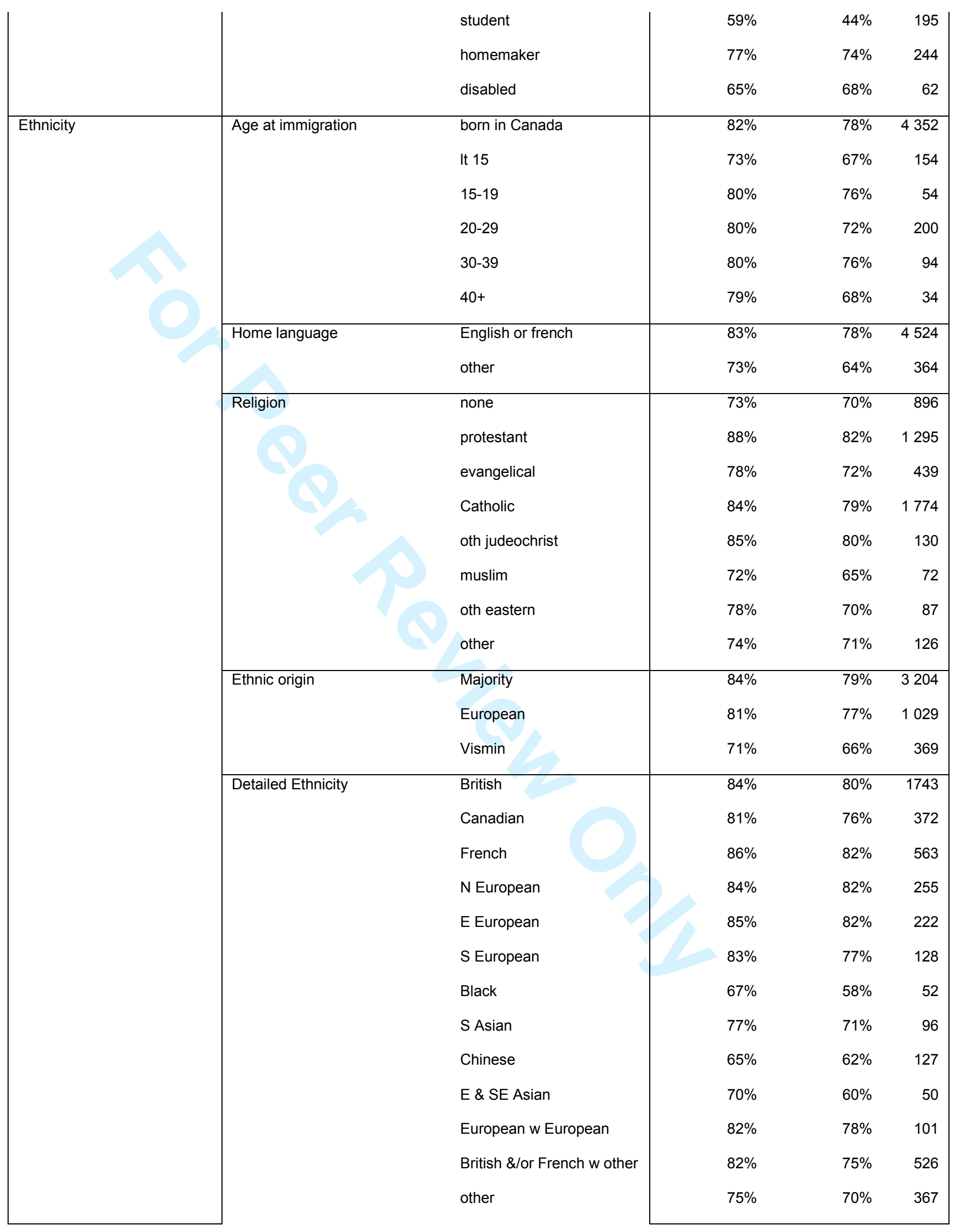




\begin{tabular}{|c|c|c|c|c|c|}
\hline \multirow[t]{4}{*}{ Trust } & \multirow[t]{4}{*}{ Trust government } & 1 & $79 \%$ & $73 \%$ & 1056 \\
\hline & & 2 & $82 \%$ & $79 \%$ & 2257 \\
\hline & & 3 & $85 \%$ & $79 \%$ & 1203 \\
\hline & & 4 & $80 \%$ & $75 \%$ & 265 \\
\hline \multirow[t]{20}{*}{ Belonging } & \multirow[t]{10}{*}{ Belonging: Canada } & feel like do not belong & $73 \%$ & $75 \%$ & 59 \\
\hline & & 2 & $71 \%$ & $80 \%$ & 51 \\
\hline & & 3 & $85 \%$ & $81 \%$ & 27 \\
\hline & & 4 & $80 \%$ & $73 \%$ & 56 \\
\hline & & 5 & $79 \%$ & $77 \%$ & 201 \\
\hline & & 6 & $71 \%$ & $70 \%$ & 167 \\
\hline & & 7 & $80 \%$ & $73 \%$ & 362 \\
\hline & & 8 & $79 \%$ & $76 \%$ & 742 \\
\hline & & 9 & $78 \%$ & $75 \%$ & 499 \\
\hline & & feel like belong completely & $85 \%$ & $79 \%$ & 2691 \\
\hline & \multirow{10}{*}{ Belonging: neighbourhood } & feel like do not belong & $60 \%$ & $62 \%$ & 63 \\
\hline & & 2 & $75 \%$ & $67 \%$ & 63 \\
\hline & & 3 & $64 \%$ & $56 \%$ & 66 \\
\hline & & 4 & $67 \%$ & $61 \%$ & 67 \\
\hline & & 5 & $72 \%$ & $62 \%$ & 314 \\
\hline & & 6 & $78 \%$ & $71 \%$ & 252 \\
\hline & & 7 & $79 \%$ & $73 \%$ & 470 \\
\hline & & 8 & $82 \%$ & $75 \%$ & 898 \\
\hline & & 9 & $84 \%$ & $80 \%$ & 532 \\
\hline & & feel like belong completely & $86 \%$ & $83 \%$ & 2115 \\
\hline \multirow[t]{11}{*}{ Current affairs awareness } & \multirow[t]{8}{*}{ Read the news } & never & $75 \%$ & $71 \%$ & 836 \\
\hline & & 1 day a week & $79 \%$ & $73 \%$ & 844 \\
\hline & & 2 & $78 \%$ & $74 \%$ & 490 \\
\hline & & 3 & $77 \%$ & $74 \%$ & 410 \\
\hline & & 4 & $82 \%$ & $76 \%$ & 200 \\
\hline & & 5 & $81 \%$ & $72 \%$ & 358 \\
\hline & & 6 & $90 \%$ & $87 \%$ & 420 \\
\hline & & 7 days a week & $89 \%$ & $84 \%$ & 1305 \\
\hline & \multirow[t]{3}{*}{ Watch the news } & never & $71 \%$ & $66 \%$ & 365 \\
\hline & & 1 day a week & $71 \%$ & $66 \%$ & 289 \\
\hline & & 2 & $77 \%$ & $71 \%$ & 346 \\
\hline
\end{tabular}




\begin{tabular}{|c|c|c|c|c|c|}
\hline & & 3 & $78 \%$ & $72 \%$ & 344 \\
\hline & & 4 & $83 \%$ & $76 \%$ & 333 \\
\hline & & 5 & $82 \%$ & $78 \%$ & 658 \\
\hline & & 6 & $87 \%$ & $87 \%$ & 218 \\
\hline & & 7 days a week & $85 \%$ & $81 \%$ & 2318 \\
\hline informal interaction & See friends & never & $76 \%$ & $67 \%$ & 221 \\
\hline & & yearly & $84 \%$ & $79 \%$ & 264 \\
\hline & & monthly & $81 \%$ & $77 \%$ & 826 \\
\hline & & weekly & $84 \%$ & $80 \%$ & 1624 \\
\hline & & biweekly & $81 \%$ & $77 \%$ & 1157 \\
\hline & & daily & $79 \%$ & $74 \%$ & 796 \\
\hline & Talk to neighbours & never & $71 \%$ & $63 \%$ & 553 \\
\hline & & yearly & $81 \%$ & $75 \%$ & 315 \\
\hline & & monthly & $82 \%$ & $75 \%$ & 830 \\
\hline & & weekly & $84 \%$ & $78 \%$ & 1255 \\
\hline & & biweekly & $84 \%$ & $83 \%$ & 978 \\
\hline & & daily & $84 \%$ & $80 \%$ & 957 \\
\hline Formal interaction & Attend religious services & never & $74 \%$ & $70 \%$ & 1509 \\
\hline & & annual & $83 \%$ & $74 \%$ & 321 \\
\hline & & biannual & $82 \%$ & $74 \%$ & 704 \\
\hline & & triannual & $85 \%$ & $81 \%$ & 520 \\
\hline & & month & $85 \%$ & $81 \%$ & 336 \\
\hline & & bimonth & $88 \%$ & $81 \%$ & 354 \\
\hline & & weekly & $88 \%$ & $85 \%$ & 1144 \\
\hline & Member: voluntary org & not a member & $77 \%$ & $70 \%$ & 1429 \\
\hline & & member & $84 \%$ & $80 \%$ & 3459 \\
\hline & Member: recreational group & not a member & $79 \%$ & $75 \%$ & 2495 \\
\hline & & member & $84 \%$ & $80 \%$ & 2393 \\
\hline
\end{tabular}




\footnotetext{
${ }^{1}$ We wish to thank Uttara Chauhan, Patrick Fafard, John Solomos and two anonymous reviewers for their for comments and suggestions.

${ }^{2}$ While some countries such as the Netherlands, Denmark and Sweden allow legally resident non-citizens to vote in local and regional elections this right is restricted to citizens in Canada.

${ }^{3}$ Voter turnout for Canadian elections can be found at the following website: http://www.sfu.ca/ aheard/elections/historical-turnout.html
} ${ }^{4}$ Detailed information on the survey can be found at the Institute for Social Research website at York University: www.yorku.ca/isr/download/esc.html ${ }^{5}$ There are about fifty respondents claiming Aboriginal origins on the dataset. These respondents were also dropped because there are too few people to get any significant results. Also, to do justice to an analysis of Aboriginal voting propensities we would have to interact Aboriginal status with the education variables which would further complicate the model.

${ }^{6}$ We note that our trust variable is different from that used by Putnam (2007) who uses a more general 'trust in others' variable. However we argue that for the purposes of a voter participation study, trust in government is a stronger indicator.

${ }^{7}$ The question used to derive ethnic origin asks about the origins of the respondent's parents and grandparents. Respondents can provide up to 4 answers. As can be seen in Appendix table 1a, the largest group is British followed by French and then Canadian. For the purposes of our research, we roll British, French and Canadian to create the majority category. 
${ }^{8}$ Wave II of the ESC does not include a weighting variable; however we have added information about the sample design (province, and the oversample information for Montreal, Toronto and Vancouver) to the model using Stata's survey set criteria. .

PIETER BEVELANDER is associate professor in the Malmö Institute of Migration, Diversity and Welfare (MIM), Malmö University, Malmö, Sweden.

ADDRESS: Malmö Institute of Migration, Diversity and Welfare (MIM), Gibraltargatan 2, 20506, Malmö. Email: Pieter.bevelander@mah.se

RAVI PENDAKUR is Assistant professor in the Department of Public and International Affairs, Univeristy of Ottawa, Ottawa, Canada.

ADDRESS: Department of Public and International Affairs, Univeristy of Ottawa, 55

Laurier E., Ottawa, Canada. Email: pendakur@uottawa.ca 